\title{
Sensory, Digestion and Texture Quality of Commercial Gluten-Free Bread: Impact of Broken Rice Flour Type
}

Feizollahi, Ehsan; Mirmoghtadaie, Leila; Mohammadifar, Mohammad Amin; Jazaeri, Sahar; Hadaegh, Haleh; Nazari, Bahman; Lalegani, Sajjad

Published in:

Journal of Texture Studies

Link to article, DOI:

$10.1111 /$ jtxs. 12326

Publication date:

2018

Document Version

Peer reviewed version

Link back to DTU Orbit

Citation (APA):

Feizollahi, E., Mirmoghtadaie, L., Mohammadifar, M. A., Jazaeri, S., Hadaegh, H., Nazari, B., \& Lalegani, S. (2018). Sensory, Digestion and Texture Quality of Commercial Gluten-Free Bread: Impact of Broken Rice Flour Type. Journal of Texture Studies, 49(4), 395-403. https://doi.org/10.1111/jtxs.12326

\section{General rights}

Copyright and moral rights for the publications made accessible in the public portal are retained by the authors and/or other copyright owners and it is a condition of accessing publications that users recognise and abide by the legal requirements associated with these rights.

- Users may download and print one copy of any publication from the public portal for the purpose of private study or research.

- You may not further distribute the material or use it for any profit-making activity or commercial gain

- You may freely distribute the URL identifying the publication in the public portal 


\title{
Sensory, Digestion and Texture Quality of Commercial Gluten-Free
}

\section{Bread: Impact of Broken Rice Flour Type}

\author{
Running title: Broken Rice Commercial Gluten-Free Bread
}

Ehsan Feizollahi ${ }^{1}{ }^{(0)}$, Leila Mirmoghtadaie ${ }^{2}$, Mohammad Amin Mohammadifar ${ }^{3 *}$, Sahar Jazaeri ${ }^{2}$, Haleh Hadaegh ${ }^{4}$ (D) Bahman Nazari $^{2}$, Sajjad Lalegani ${ }^{5}$

${ }^{1}$ Student's Research Committee, National Nutrition and Food Technology Research Institute, Shahid Beheshti University of Medical Sciences, Tehran, Iran

${ }^{2}$ Department of Food Science and Technology, National Nutrition and Food Technology Research

Institute, Faculty of Nutrition Sciences and Food Technology, Shahid Beheshti University of Medical Sciences, Tehran, Iran

${ }^{3}$ Food Production Engineering, DTU Food, Technical University of Denmark, Søltofts Plads 227, Dk-2800 Lyngby, Denmark

${ }^{4}$ Department of Food Science and Technology, Tehran Science and Research Branch, Islamic Azad University, Tehran, Iran

5 Department of Food Science and Technology, Faculty of Agriculture, Tarbiat Modares University, Tehran, Iran

*Corresponding authors: Leila Mirmoghtadaie,

Department of Food Science and Technology, National Nutrition and Food Technology Research Institute, Faculty of Nutrition Sciences and Food Technology, Shahid Beheshti University of Medical Sciences, Tehran, Iran, Email: mirmoghtadaie@sbmu.ac.ir, Le mirmoghtadaie@yahoo.com

* Mohammad Amin Mohammadifar, Food Production Engineering, DTU Food, Technical University of Denmark, Søltofts Plads 227, Dk-2800 Lyngby, Denmark. Email: mohamdif@ut.ac.ir, moamo@food.dtu.dk

This article has been accepted for publication and undergone full peer review but has not been through the copyediting, typesetting, pagination and proofreading process which may lead to differences between this version and the Version of Record. Please cite this article as an 'Accepted Article', doi: 10.1111/jtxs.12326

This article is protected by copyright. All rights reserved. 


\section{Abstract}

This research investigated the effects of two varieties of broken rice (Khouzestan and Lenjan) from warm and dry regions, and two (Hashemi and Tarom) from mild and humid regions on different parameters including dough rheology, digestibility and quality (color, specific volume, textural properties and sensorial properties) of a commercial gluten-free bread. Furthermore, the rice varieties' hydration properties, gelatinization temperatures and starch-granule morphology were assessed. Significant differences were observed in the varieties' proximate composition and hydration properties from both climate zones. The granules' average size was 3.17-4.9 $\mu \mathrm{m}$. The specific volume of the breads showed no correlation with either the damaged starch content or the amylose content, but had a significant negative correlation with hardness $(\mathrm{r}=-0.923, \mathrm{P}<0.05)$. The crumb hardness of bread was positively correlated with water-binding capacity and was affected by elastic modulus of dough. Results of predicted glycemic index were in accordance with total carbohydrates. Khouzestan received the highest score in sensory evaluation test. Based on the outcomes for bread-quality attributes, Khouzestan from the warm and dry region, which is a cheaper rice variety in Iran, was the most appropriate variety for gluten-free bread production. Moreover, it was determined that the rice varieties currently used in commercial manufacture of gluten-free bread do not necessarily yield the highest-quality bread.

Keywords: Rice, Gluten-free bread, Digestion, Texture

\section{Practical applications}

Gluten-free breads (GFBs) are generally used by Coeliac patients. In comparison to wheat bread, the quality of GFBs is lower. Rice is one of the main ingredients of GFBs' formulation, thence by determining the quality-related features of the rice, improvement in the final product could be achieved. In addition, by implementing the cheap and the broken rice variety, the price of the final product could be decreased and be more affordable for the patients. 


\section{Introduction}

Bakery products, especially bread, form the basis of most people's diet (Kihlberg \& Risvik, 2007). Bread is one of the world's most popular food product because of its relatively high nutritional value and unique sensory characteristics (texture, taste and flavor). However, a number of people suffer from coeliac disease (CD) (Matos Segura \& Rosell, 2011) or other gluten sensitivities. Intolerance to gluten in coeliac patients is lifelong; lifetime adherence to a gluten-free diet is the only solution (Nicolae, Radu, \& Belc, 2016).

Rice as a gluten-free cereal has a neutral flavor and white color, easy digestibility and low levels of sodium, and it has hypoallergenic properties (Matos \& Rosell, 2013). These features lead rice flour to be a desirable ingredient for producing gluten-free bakery products. The physicochemical properties of rice flour are significantly influenced by the rice variety (Fabiola Cornejo \& Cristina M. Rosell, 2015), protein (Marcoa \& Rosell, 2008; Sun, Hou, \& Zhang, 2008), lipid, moisture (Dautant, Simancas, Sandoval, \& Müller, 2007) and amylose content (Varavinit, Shobsngob, Varanyanond, Chinachoti, \& Naivikul, 2003). There is a general opinion that the amylose content of each variety is a primary factor influencing the bread quality in gluten-free breads, but it is not influential enough by itself to allow a prediction of bread quality (Han, Cho, Kang, \& Koh, 2012). Several other factors, such as gelatinization properties and damaged starch content of flour, must be considered in producing high-quality, gluten-free rice bread. Some rice is damaged during refining into white rice; the damaged grains are discarded as "broken rice". Wastage for this reason is high in Iran. Furthermore, gluten-free products are prohibitively expensive for most coeliac patients. One of the best ways to surmount this issue is to use riceprocessing wastage in gluten-free formulations, particularly gluten-free bread. Furthermore, information about the physicochemical properties of broken-rice varieties, and the effects of different cultivation conditions on the rice or the quality of gluten-free bread made from each variety is little. The rice varieties we chose were from two different climate zones; two varieties were more expensive than the others.

Gluten is responsible for the viscoelastic properties of dough, which is essential for maintenance of yeast-produced gas in bread structure (Ngemakwe, Le Roes-Hill, \& 
Jideani, 2015; Nicolae et al., 2016). Gluten-free dough has neither cohesiveness nor elastic properties; the resulting dough is more fluid than wheat dough, similar to cake batters in terms of viscosity and rheological properties. Consequently, the baked bread has poor color and crumbling texture, and shows other post-baking defects (Ngemakwe et al., 2015). It is important to define GFBs' sensory characteristics, including texture, appearance, taste, and aroma that are appealing to coeliac consumers, as to date most GFBs have exhibited poor quality and consumer acceptability, especially in comparison to traditional wheat flour yeast bread.

The glycemic index of bread is also an important aspect that should be considered in gluten-free products because of the relatively high prevalence of type I diabetes mellitus in coeliac patients (Murray, 2005; Smyth et al., 2008). Therefore, it is necessary for patients to maintain acceptable glycemic control while following a strict gluten-free diet.

This study is the first to compare the macronutrients of broken rice from two climate zones and investigate the dough rheology, sensory, digestibility and quality of bread made with these varieties with those of commercial gluten-free bread.

\section{Materials and methods}

\subsection{Materials}

Four varieties of broken rice were used: three (Hashemi, Khouzestan, Lenjan) grown in two regions of Iran with different climate zones and one (Tarom) used by a company making gluten-free products. Hashemi and Tarom, cultivated in mild and humid regions were more expensive than the other samples; Khouzestan and Lenjan, cultivated in warm and dry regions, were less expensive. All varieties were harvested between August and November 2015. The broken kernels were milled (Maadani Machinery Mill, Iran) with a $500 \mu \mathrm{m}$ screen.

\subsection{Flour characterization}

The protein, damage starch, amylose, lipid, ash and moisture content of rice flours milled from each sample were analyzed following AACC (11 ${ }^{\text {th }}$ edition $)$ methods, showing values 
of 46-11/02, 76-30/02, 61-03/01, 30-25/01, 08-01/01 and 44-01/01, respectively. All the analyses were done in triplicate.

\subsection{Flour hydration}

The samples' water-holding capacity (WHC) and water-binding capacity (WBC) were evaluated according to the procedure described by Cornejo and Rosell (F. Cornejo \& C. M. Rosell, 2015). WHC was determined by mixing $1.000 \mathrm{~g} \pm 0.005 \mathrm{~g}$ of flour with $10 \mathrm{ml}$ of distilled water and maintaining it at room temperature for $24 \mathrm{~h}$, after which the supernatant was removed.

WBC was determined by mixing $1.000 \mathrm{~g} \pm 0.005 \mathrm{~g}$ flour with $10 \mathrm{ml}$ of distilled water and centrifuging the mixture at 2,000 $\times \mathrm{g}$ for10 min. WHC and $\mathrm{WBC}$ were expressed as grams of water retained per gram of solid. All the analyses were made in triplicate.

\subsection{Gelatinization temperatures}

Gelatinization was evaluated using differential scanning calorimetry (NETZSCH, 200 F 3 Maia, Germany). Flour samples (dry-weight basis) and distilled water were added to aluminum pans in a ratio of 1:3. The pans were hermetically sealed and placed at room temperature for $1 \mathrm{~h}$ before analysis and heated from 20 to $120{ }^{\circ} \mathrm{C}$ at a rate of $10{ }^{\circ} \mathrm{C} / \mathrm{min}$. Indium was used for calibration and an empty pan was used as a reference. The transition temperatures (onset $\left(\mathrm{T}_{\mathrm{o}}\right)$, peak $\left(\mathrm{T}_{\mathrm{p}}\right)$ and conclusion $\left(\mathrm{T}_{\mathrm{c}}\right)$ ) and the enthalpy of gelatinization $(\Delta \mathrm{H})$ were measured. In addition, the gelatinization temperature range $\left(\mathrm{I}_{\mathrm{g}}\right)$ and the peak height index (PHI) were calculated as shown in equations (1) and (2). PHI describes the relative shape of the endotherm. Low PHI values represent a less structured starch matrix (Correia \& Beirão-da-Costa, 2012).

$$
I_{g}=T_{c}-T_{o} \quad(1) \quad P H I=\Delta \mathrm{H} / T_{p^{-}} T_{c}
$$

\subsection{Scanning electron microscopy}

To analyze the morphology of starch granules, alkaline extraction of starch (Souza, Sbardelotto, Ziegler, Marczak, \& Tessaro, 2016) from rice varieties was performed first. 
Then starch samples were affixed to aluminum stubs with double-sided carbon tape and coated with sputtered gold (KYKY, sbc-12 sputter coater, china). An acceleration potential of $26 \mathrm{kV}$ was used in scanning electron microscopy (SEM) (KYKY, EM3200, China). The diameter of the starch granules was measured by averaging the largest dimension of 20 starch granules at 2500x magnification from three micrographs.

\subsection{Dynamic oscillatory test}

To identify the doughs' viscous and elastic features, dynamic oscillatory tests were performed. Dynamic tests on dough (all ingredients without yeast) were carried out with an MCR 301 rheometer (Anton Paar, Austria) using serrated parallel plate geometry (40-mm diameter). The gap was adjusted to $1-\mathrm{mm}$. Petroleum jelly (Vaseline) was used to cover the exposed sample surfaces. Before evaluation, the dough was set to relax for $5 \mathrm{~min}$. First, a strain sweep test (0.1-200\%) was performed at $25{ }^{\circ} \mathrm{C}$ with a constant frequency of $1 \mathrm{~Hz}$ to identify the linear viscoelastic region (LVR). Based on the results, $0.1 \%$ constant strain was used in a frequency sweep test at $25^{\circ} \mathrm{C}$ with a frequency range of $0.1-100-\mathrm{Hz}$. The dynamic rheological properties of the samples were measured by the storage modulus $\left(\mathrm{G}^{\prime}\right.$ [Pa]) (elastic modulus), loss modulus $\left(\mathrm{G}^{\prime \prime}[\mathrm{Pa}]\right)$ (viscous modulus) and $\tan \delta\left(\mathrm{G}^{\prime \prime} / \mathrm{G}^{\prime}\right)$ for different frequency values (Hz) (C. M. Mancebo, San Miguel, Martínez, \& Gómez, 2015).

\subsection{Preparation of gluten-free rice bread}

Gluten-free breads were prepared according to the formula for a popular gluten free bread manufactured by an Iranian company. All gluten-free formulations contained rice flour, potato flour, corn starch, instant yeast, sunflower oil, salt, sugar, water and stabilizers. Rice flour constituted $50 \%$ of the dry ingredients by weight and water to the weight of $80 \%$ of the dry ingredients' weight was added. All dry ingredients were mixed in a spiral mixer (Diosna, Germany) for $5 \mathrm{~min}$. Then oil and water were added gently and mixed for $5 \mathrm{~min}$ at 1 rpmf. After mixing, $240 \mathrm{~g}$ of each dough was put into pans $(25 \times 11 \times 5.55 \mathrm{~cm})$ and fermented for $20 \mathrm{~min}$ at $35{ }^{\circ} \mathrm{C}$ and $85 \% \mathrm{RH}$. Finally, the baking process was carried out at $185^{\circ} \mathrm{C}$ for $20 \mathrm{~min}$. Breads were kept for $2 \mathrm{~h}$ at room temperature before evaluation. 


\subsection{Crumb-color measurement}

The crumb color was determined using a SP64 Portable Sphere Spectrophotometer (X.Rite, USA) according to the standard ASTM E308 (ASTM E308-15). L* (0 =black, 100 $=$ white $), a^{*}(+$ value $=$ red, - value $=$ green $)$, and $b^{*}(+$ value $=$ yellow,-value $=$ blue $)$ values were recorded from three different areas of the bread crumb.

\subsection{Measurement of specific volume and crumb textural properties}

The breads' volume was determined using the rapeseed displacement method. Specific volume $\left(\mathrm{cm}^{3} / \mathrm{g}\right)$ was calculated as the ratio of the volume $\left(\mathrm{cm}^{3}\right)$ to the weight of the bread (g) (Fabiola Cornejo \& Cristina M. Rosell, 2015).

Texture measurements were performed by a TA.XT Plus texture analyzer (Stable Micro Systems Ltd., Surrey, UK) according to the AACC (2000) Approved Method 74-09 (AACC International. Approved Methods of Analysis) with a slight modification. A slice of the crumb measuring $20 \times 20 \times 25 \mathrm{~mm}$ was compressed to $40 \%$ of its original height at a crosshead speed of $100 \mathrm{~mm} / \mathrm{min}$ with a $36 \mathrm{~mm}$ cylinder probe using a $5 \mathrm{~kg}$ load cell (Kittisuban, Ritthiruangdej, \& Suphantharika, 2014). The analysis was carried out at $20 \pm 3$ ${ }^{\circ} \mathrm{C}$ on bread slices. The resulting TPA curves were used to measure hardness, cohesiveness, springiness, resilience and chewiness of the crumb. The average of six replicates was reported.

\subsection{In vitro starch digestibility and predicted glycemic index}

In vitro starch digestibility was performed to mimic the hydrolysis reactions in the human intestine as described by Brennan and Tudorica (Brennan \& Tudorica, 2008). It involves simulated mastication, a proteolytic stage followed by incubation for mimicking the belly, and restriction of pancreatic a-amylase by dialysis tubings for mimicking intestine. Dialysis tubings, chemicals and enzymes were obtained from Sigma-Aldrich, Arklow, Ireland. Triplicate samples of homogenized gluten-free and wheat breadcrumb $(4 \pm 0.001 \mathrm{~g})$ 
"as eaten" were mixed with $20 \mathrm{~mL}$ sodium-potassium phosphate buffer ( $\mathrm{pH}$ 6.9). The $\mathrm{pH}$ was adjusted to 1.5 using concentrated hydrochloric acid $(12 \mathrm{~N})$, which is appropriate for porcine pancreatic pepsin activity. Samples were incubated for $30 \mathrm{~min}$ at $37{ }^{\circ} \mathrm{C}$ with $5 \mathrm{~mL}$ pepsin solution (EC 3.4.23.1; porcine gastric mucosa, $115 \mathrm{U} / \mathrm{mL}$ ). The $\mathrm{pH}$ was then adjusted to 6.9 with $\mathrm{NaOH}(12 \mathrm{~N})$, and $\alpha$-amylase solution (EC 3.2.1.1; porcine pancreatic; $110 \mathrm{U} / \mathrm{mL}$ in TRIS $\mathrm{HCl}$ buffer) was added. Finally, samples were brought to $50 \mathrm{~mL}$ with a sodium-potassium phosphate buffer and the mixtures were transferred into dialysis tubings (molecular weight cut-off $11331 \mathrm{Da}$ ). Each tube was transferred into a beaker containing $450 \mathrm{~mL}$ potassium phosphate buffer and incubated in a shaking incubator $\left(5 \mathrm{~h}\right.$ at $37{ }^{\circ} \mathrm{C}$, $100 \mathrm{rpm})$. An aliquot of dialysate was withdrawn every $30 \mathrm{~min}$ for quantification of reducing sugar content, and replaced each time with the equal amount of sodium potassium phosphate buffer. The amount of reducing sugars in the withdrawn dialysates (DNS) was measured using the 3,5 dinitrosalicylic acid method. Thereafter, $200 \mathrm{~mL}$ dialysate was boiled for $10 \mathrm{~min}$ together with $200 \mathrm{~mL}$ 3,5-dinitrosalicylic acid (DNS) reagent. Absorbance was measured at $546 \mathrm{~nm}$. A standard curve using maltose (Sigma-Aldrich, Ireland) was prepared. The DNS solution was prepared by mixing solution A (10 g of 3,5 dinitrosalicylic acid powder in $200 \mathrm{~mL} 2 \mathrm{~N} \mathrm{NaOH}$ ) and solution $\mathrm{B}$ (300 g potassium sodium tartrate tetrahydrate in $500 \mathrm{~mL}$ distilled water) and adjusting the volume to $1 \mathrm{~L}$ with distilled water. For quantification of reducing sugars released (\% RSR), hydrolysis index (HI) (area under the curve (AUC) from 0 to $180 \mathrm{~min}$ as a percentage of the corresponding area of the reference white wheat bread) and the predicted GI, the following equations were used:

$\% R S R=$ A sample $\times 500 \times 0.95 /$ A maltose $\times$ carbohydrate $\times 100$

A sample $=$ sample absorbance at $546 \mathrm{~nm}$

A maltose $=$ absorbance of solution containing maltose $(1 \mathrm{mg} / \mathrm{ml})$

Carbohydrate $=m g$ starch and sugars contained in $4 \mathrm{~g}$ sample

$H I=A U C(0-180 \mathrm{~min})$ sample/AUC (0-180min) wheatbread $\times 100$

$G_{\text {predicted }}=0.862 \mathrm{HI}+8.189$ 
The amount of carbohydrates available in $4 \mathrm{~g}$ of bread was calculated based on the following formula: [100 - (moisture + fat + protein + ash $)]$.

\subsection{Sensory evaluation}

Sensory analysis of the breads was carried out by 20 semi-trained panelists, both male and female, to evaluate color, texture, appearance, taste, odor and overall acceptability in a five-point hedonic scale ( $1=$ dislike extremely, $3=$ neither like nor dislike, $5=$ like extremely). The samples were coded and evaluated at room temperature.

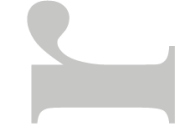

\subsection{Statistical analysis}

The results were expressed as mean values. Significance differences in treatment means were identified by one-way analysis of variance (ANOVA) followed by Duncan's multiple range tests at $\mathrm{p} \leq 0.05$ (IBMSPSS v.21, Armonk, NY). The sensory data were analyzed using independent samples t-test.

\section{Results and discussion}

\subsection{Proximate analysis, WHC and WBC}

Significant differences were seen in the proximate analysis and hydration properties of different rice flours (Table 1). Lenjan had the highest content of damaged starch, followed by Hashemi, Khouzestan and Tarom

\section{[Table 1 here]}

The apparent amylose contents (AACs) of the rice flours were intermediate (A. A. Wani et al., 2012), and varied between 21.38 and $25.72 \%$. In contrast, the fat content ranged from 0.74 to $2.96 \%$. Khouzestan had the highest protein, ash and moisture content, while Hashemi showed the lowest AAC, protein and moisture content. Lenjan exhibited the highest $\mathrm{AAC}$ and the lowest WBC; this was in agreement with the trend reported by Gani et al (Gani, Wani, Masoodi, \& Salim, 2013). However, Hashemi, with the lowest AAC, did not follow the trend; this was likely due to other factors such as particle size, molecular 
structure and hydrophilic parts of proteins and carbohydrates (Gani et al., 2013; I. A. Wani, Sogi, Wani, \& Gill, 2013). WBC and WHC are important factors for making gluten-free breads. Low WBC is a factor in making a fresh bread with suitable volume and firmness (Han et al., 2012). High WHC could retard staling by interfering in starch retrogradation in gluten-free bread (Sciarini, Ribotta, León, \& Pérez, 2010) .Tarom had the highest WHC. Overall, varieties from warm and dry regions had more AAC, ash, fat and protein than varieties from mild and humid regions.

\subsection{Starch-granule morphology}

SEM images of rice starch granules are presented in fig. 1. The granules' microstructure was mainly polyhedral, with an average granule size of 3.17-4.9 $\mu \mathrm{m}$.

[Figure 1 here]

Khouzestan starch had the smallest granules, at an average of $3.17 \mu \mathrm{m}$; Hashemi starch had the largest granules, at an average of $4.9 \mu \mathrm{m}$. Lenjan and Tarom had average starchgranule sizes of $3.35 \mu \mathrm{m}$ and $3.68 \mu \mathrm{m}$ respectively. Khouzestan and Lenjan cultivated in warm and dry regions had smaller granules than Hashemi and Tarom cultivated in mild and humid regions. Starch-granule size is an important factor affecting the composition, gelatinization, pasting properties, swelling, solubility and crystallinity of starch (A. A. Wani et al., 2012).

\subsection{Gelatinization parameters of rice flour}

The flours' gelatinization temperatures ranged from 70.7 to $83.4{ }^{\circ} \mathrm{C}$ (Fig. 2). There were no significant differences $(\mathrm{p}>0.05)$ in the samples' peak temperature (Tp), gelatinization enthalpy $(\Delta \mathrm{H})$ or peak height index $(\mathrm{PHI})$; this was consistent with the results obtained by SEM (Fig. 1). The studied rice varieties' starch granules were similar in shape, and the range of average granule sizes was small, which may explain the similarity in gelatinization temperatures. Gelatinization enthalpy may be attributed to the enthalpy of amylose-lipid complex formation during heating (Juliano, 1998), and can reflect the loss of 
molecular order (double-helical) (N. Singh, Kaur, Sandhu, Kaur, \& Nishinari, 2006). Low $\Delta \mathrm{H}$ values represent lower stability of crystals in starch (Chiotelli \& Le Meste, 2002). Gelatinization temperatures were high but similar to those reported by other authors in studies of rice flour and starch (Ahmed, Ramaswamy, Ayad, \& Alli, 2008; Fabiola Cornejo \& Cristina M. Rosell, 2015; N. Singh et al., 2006). A high degree of crystallinity can be a reason for high gelatinization temperatures in rice flour (N. Singh et al., 2006). The differences seen in $T_{o}$ and $I_{g}$ among the rice cultivars examined in this study might be due to differing amounts of longer-chain amylopectins (Yamin, Lee, Pollak, \& White, 1999).

\section{[Figure 2 here]}

[Table 2 here] Tarom showed the highest $\mathrm{T}_{\mathrm{o}}$ and $\mathrm{T}_{\mathrm{p}}$, while Lenjan showed the lowest $\mathrm{T}_{\mathrm{o}}$, $\mathrm{T}_{\mathrm{p}}, \Delta \mathrm{H}$ and $\mathrm{PHI}$; that could be attributed to with each variety's damaged starch content (Table 1). Intact starch granules (less starch damage) need more energy to be gelatinized (Asmeda, Noorlaila, \& Norziah, 2016). Higher contents of damaged starch accelerate the water absorption and swelling that result in lower gelatinization temperatures (Asmeda et al., 2016). The results did not show a significant correlation between amylose content and gelatinization parameters; this is in agreement with the results of Cornejo and Rosell (F. Cornejo \& C. M. Rosell, 2015).

\subsection{Dough rheology}

The viscoelastic behavior of the dough samples was studied using oscillation frequency sweep experiment. At all frequencies tested, the storage modulus $\left(\mathrm{G}^{\prime}\right)$ was higher than the loss modulus $\left(\mathrm{G}^{\prime \prime}\right)$ in all dough samples, which represents the prevalence of elastic features to the viscous character of the dough. Hence $\tan \delta$, ratio of the lost energy to the stored energy per cycle, was lower than 1 for all dough samples (Fig. 3). A solid elastic-like behavior was seen due to a slight rise in storage and loss modulus with increase in frequency (Lazaridou, Duta, Papageorgiou, Belc, \& Biliaderis, 2007). Tan $\delta$ rose by increasing frequency, which shows the transition of solid-like to liquid-like behavior in samples at higher frequency ranges. Tarom dough had the lowest tan $\delta$ than all the other doughs, this represents the stiffness of this sample in comparison to the others. 
[Figure 3 here]

These results were in relation with the samples' damaged starch content and WBC (Table 1). Tarom, with the highest WBC, possessed the highest $G^{\prime}$ and $G^{\prime \prime}$ and the lowest damaged starch content. In contrast, Lenjan, with the highest damaged starch content and lowest WBC, showed the lowest $\mathrm{G}^{\prime}$ and $\mathrm{G}^{\prime \prime}$ along with Khouzestan. The differences in dough rheology could be related to the internal structure of the starch in each flour, the more damaged starch leading to enhanced water binding and reduced elastic modulus of flour and dough (C. Mancebo, Merino, Martínez, \& Gómez, 2015). There was not any relation between protein content and rheological properties of the dough within samples that could be due to moderate effect of protein on water absorption of dough (Dexter, Preston, Martin, \& Gander, 1994; Tara, Bains, \& Finney, 1972). The varieties from mild and humid region had higher storage modulus than the ones from warm and dry region due to having greater amount of AAC and WBC.

\subsection{Crumb color}

Table 3 summarizes the $\mathrm{L}^{*}$, $\mathrm{a}^{*}$ and $\mathrm{b}^{*}$ values for all the breads' crumb. The color of the crumb is an important feature of GFBs. The $\mathrm{L}^{*}$ value indicates the lightness of the crumb, and many studies consider it the most important color parameter (Nunes, Ryan, \& Arendt, 2009; Sabanis \& Tzia, 2011). In the current study, the L* value ranged from 70 to 76 in bread samples; this was consistent with previous reports (Fabiola Cornejo \& Cristina M. Rosell, 2015; Matos \& Rosell, 2012, 2013). Among the rice-bread samples, Khouzestan resulted in a darker crumb color, which could be considered more desirable because it causes the bread to more closely resemble wheat breads than other GFBs, which tend to be obviously lighter (Gallagher, Kunkel, Gormley, \& Arendt, 2003).Actually, in our study, varieties from warm and dry regions (Khouzestan, Lenjan) were darker than those from mild and humid regions (Hashemi, Tarom). The a* values were negative, which indicates the lack of red hue for the crumbs. The $b^{*}$ scale showed a positive value (yellow hue) for all the evaluated samples. Lenjan showed a significantly higher $b^{*}$ value than did the other samples. 
[Table 3 here]

\subsection{Specific volume and textural properties}

Table 4 gives the specific volume and textural properties of the GFBs in this study. Specific volume is one of the important features of breads, and is a key parameter in evaluating bread quality. Tarom (the variety from mild and humid region used by the company manufacturing the commercial gluten-free bread and used in this study) had the lowest specific volume and the highest G', in contrast to the Khouzestan cultivated in the warm and dry region. In fact, dough systems with excessive elasticity lead to limited gascell expansion during proofing.(Lazaridou et al., 2007) No correlation was found between amylose content and specific volume of the bread, as was also reported by Cornejo et al (Fabiola Cornejo \& Cristina M. Rosell, 2015).

\section{[Table 4 here]}

As seen for Tarom, the specific volume of the breads were depended on WBC; this agrees with previous research (Han et al., 2012). Although, a negative correlation between the specific loaf volume and damaged starch content has also been reported (Araki et al., 2009), this correlation was not evident in our breads with the commercial formula. This could be due to the effects of other parameters such as the storage modulus of the dough and WBC of the flours.

Table 4 gives the crumb texture properties. Crumb hardness ranged from $2.20 \mathrm{~N}$ to $4.14 \mathrm{~N}$, softer than commercial GFBs as reported by Matos and Rosell (Matos \& Rosell, 2012). Crumb hardness had a negative correlation with specific volume $(\mathrm{r}=-0.923, \mathrm{P}<0.05)$ and positive correlation with WBC $(\mathrm{r}=0.958, \mathrm{P}<0.05)$; this was most obvious for the Tarom and Khouzestan varieties. Tarom had significant differences with the other varieties in almost all the textural properties. There was no significant difference in springiness among the samples, which indicates the freshness and elasticity of the bread. Cohesiveness represents the extent to which the material deforms before it ruptures. The cohesiveness of the Tarom variety was significantly higher than that of the other breads. Breads with low cohesiveness are more susceptible to fracturing or crumbling, which makes them less 
desirable (Matos \& Rosell, 2012). Breads with low chewiness are broken easily in the mouth. Tarom had the highest chewiness and Khouzestan had the lowest. As previously reported by Matos and Rosell (Matos \& Rosell, 2012), hardness and chewiness showed similar trends. Among the breads, Tarom showed the highest resilience, which can be taken to represent the ability to recover after compression. Amylose molecules play an important role in the formation of bread's crumb structure (Kang, Sohn, Yoon, Lee, \& Ko, 2015), but no correlation was found in this study between textural properties and amylose content. This could be due to other factors influencing the structure, such as interactions among proteins, lipids and carbohydrates and their synergic effects.

\subsection{Predicted glycemic index}

A dialysis system was used to investigate the in vitro digestion of rice-bread samples as eaten. The HI and GI indices of the rice-bread samples were predicted as in vitro in this study. Previous studies have confirmed that there is a correlation between the rate of starch uptake in vivo, as judged from the postprandial glucose response, and the rate of in vitro amylolysis when applying the dialysis system (Björck, Granfeldt, Liljeberg, Tovar, \& Asp, 1994; Goñi, Garcia-Alonso, \& Saura-Calixto, 1997). As expected, the control wheat bread had a much higher reducing sugars release than did the rice-bread samples.

\section{[Figure 4 here]}

In fact, the rice-bread samples showed a slower rate of starch digestion compared to the control wheat bread. After 300 min of in vitro digestion, the percentage of reducing sugars released in all rice-bread samples was significantly lower than in the control wheat bread.

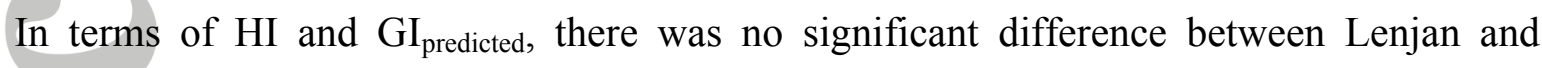
Khouzestan breads, which showed the lowest values (Figure 4, Table 5). Results were in accordance with total carbohydrates: Hashemi, with the highest level of carbohydrates, presented the highest $\mathrm{GI}_{\text {predicted. }}$ Furthermore, a substantial negative correlation was observed between $\mathrm{GI}_{\text {predicted }}$ and AAC $(\mathrm{r}=-0.972, \mathrm{P}<0.05)$, as had been reported before ( $\mathrm{J}$. Singh, Dartois, \& Kaur, 2010). Hashemi, with the lowest AAC, had the highest GI $\mathrm{I}_{\text {predicted. }}$ The results of $\mathrm{GI}_{\text {predicted }}$ were associated with starch-granule size; this was in contrast with 
previous studies (Capriles, Coelho, Guerra-Matias, \& Arêas, 2008; Tester, Qi, \& Karkalas, 2006). This could be due to unexpectedly large effects of other parameters, such as AAC and carbohydrate content. Overall, the warm and dry varieties had lower $\mathrm{GI}_{\text {predicted }}$ due to the discussed parameters in this section.

\section{[Table 5here]}

\subsection{Sensory evaluation}

According to sensory results, the GFBs differed significantly $(p<0.05)$ in crumb appearance and color (Table 6). Tarom showed the least acceptable appearance and color score. Kouzestan received the highest scores for odor, taste and texture. The scores that participants gave to texture were associated with the specific volume and hardness of the crumbs. In overall acceptability, Khouzestan received the highest score: 4.27 out of 5 . The results of the color evaluation demonstrate that consumers prefer darker colors, which could be determined from the crumb-color results.

[Table 6 here]

\section{Conclusions}

In summary, AAC, WBC and damaged-starch content were the crucial factors in determining bread quality. In our study, WBC was a key parameter in determining the dough rheology, specific volume and crumb hardness. AAC was associated with $\mathrm{GI}_{\text {predicted. }}$. The content of damaged-starch can alter the gelatinization temperatures and dough rheology. Among the varieties being analyzed, Khouzestan had the highest specific volume and sensorial properties, and possessed a low predicted glycemic index. Furthermore, it represented the lowest hardness. Hence, it was chosen as the best variety for making gluten-free bread. Rice varieties (Khouzestan and Lenjan) cultivated in warm and dry regions with cheaper prices could be used instead of varieties (Hashemi and Tarom) being cultivated in mild and humid regions with higher prices. Moreover, varieties being used commercially are not necessarily the best ones for bread making, as shown by the results 
for Tarom. In fact, could potentially increase both profit and product quality by using specific cheaper varieties.

\section{Ethical Statements}

Conflict of Interest: The authors declare that they do not have any conflict of interest.

Ethical Review: This study was approved by the Institutional Review Board of Shahid Beheshti University of Medical Sciences.

Informed Consent: Written informed consent was obtained from all study participants.

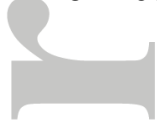

\section{References}

AACC International. Approved Methods of Analysis, t. E. M.-M. o. B. F. b. U. T. M. A. N., 1999. AACC International, St. Paul, MN, U.S.A. http://dx.doi.org/10.1094/AACCIntMethod-7409.01.

Ahmed, J., Ramaswamy, H. S., Ayad, A., \& Alli, I. (2008). Thermal and dynamic rheology of insoluble starch from basmati rice. Food Hydrocolloids, 22(2), 278-287.

Araki, E., Ikeda, T. M., Ashida, K., Takata, K., Yanaka, M., \& lida, S. (2009). Effects of rice flour properties on specific loaf volume of one-loaf bread made from rice flour with wheat vital gluten. Food Science and Technology Research, 15(4), 439-448. doi:10.3136/fstr.15.439

Asmeda, R., Noorlaila, A., \& Norziah, M. (2016). Relationships of damaged starch granules and particle size distribution with pasting and thermal profiles of milled MR263 rice flour. Food Chemistry, 191, 45-51.

ASTM E308-15, S. P. f. C. t. C. o. O. b. U. t. C. S., ASTM International, West Conshohocken, PA, 2015, www.astm.org.

Björck, I., Granfeldt, Y., Liljeberg, H., Tovar, J., \& Asp, N.-G. (1994). Food properties affecting the digestion and absorption of carbohydrates. The American journal of clinical nutrition, 59(3), 699S-705S.

Brennan, C. S., \& Tudorica, C. M. (2008). Evaluation of potential mechanisms by which dietary fibre additions reduce the predicted glycaemic index of fresh pastas. International Journal of Food Science \& Technology, 43(12), 2151-2162. doi:10.1111/j.1365-2621.2008.01831.x

Capriles, V., Coelho, K., Guerra-Matias, A., \& Arêas, J. (2008). Effects of processing methods on amaranth starch digestibility and predicted glycemic index. Journal of Food Science, 73(7), H160-H164.

Chiotelli, E., \& Le Meste, M. (2002). Effect of small and large wheat starch granules on thermomechanical behavior of starch. Cereal Chemistry, 79(2), 286-293.

Cornejo, F., \& Rosell, C. M. (2015). Influence of germination time of brown rice in relation to flour and gluten free bread quality. Journal of Food Science and Technology. doi:10.1007/s13197-015-1720-8

Cornejo, F., \& Rosell, C. M. (2015). Physicochemical properties of long rice grain varieties in relation to gluten free bread quality. LWT - Food Science and Technology, 62(2), 12031210. doi:10.1016/j.Iwt.2015.01.050 
Correia, P., \& Beirão-da-Costa, M. L. (2012). Effect of drying temperatures on starch-related functional and thermal properties of chestnut flours. Food and Bioproducts Processing, 90(2), 284-294. doi:10.1016/j.fbp.2011.06.008

Dautant, F., Simancas, K., Sandoval, A., \& Müller, A. (2007). Effect of temperature, moisture and lipid content on the rheological properties of rice flour. Journal of Food Engineering, 78(4), 1159-1166.

Dexter, J., Preston, K., Martin, D., \& Gander, E. (1994). The effects of protein content and starch damage on the physical dough properties and bread-making quality of Canadian durum wheat. Journal of Cereal Science, 20(2), 139-151.

Gallagher, E., Kunkel, A., Gormley, T. R., \& Arendt, E. K. (2003). The effect of dairy and rice powder addition on loaf and crumb characteristics, and on shelf life (intermediate and long-term) of gluten-free breads stored in a modified atmosphere. European Food Research and Technology, 218(1), 44-48. doi:10.1007/s00217-003-0818-9

Gani, A., Wani, S., Masoodi, F., \& Salim, R. (2013). Characterization of rice starches extracted from Indian cultivars. Food Science and Technology International, 19(2), 143-152.

Goñi, l., Garcia-Alonso, A., \& Saura-Calixto, F. (1997). A starch hydrolysis procedure to estimate glycemic index. Nutrition Research, 17(3), 427-437. doi:http://dx.doi.org/10.1016/S02715317(97)00010-9

Han, H. M., Cho, J. H., Kang, H. W., \& Koh, B. K. (2012). Rice varieties in relation to rice bread quality. J Sci Food Agric, 92(7), 1462-1467. doi:10.1002/jsfa.4727

Juliano, B. (1998). Varietal impact on rice quality. Cereal foods world (USA).

Kang, T. Y., Sohn, K. H., Yoon, M. R., Lee, J. S., \& Ko, S. (2015). Effect of the shape of rice starch granules on flour characteristics and gluten-free bread quality. International Journal of Food Science and Technology. doi:10.1111/ijfs.12835

Kihlberg, I., \& Risvik, E. (2007). Consumers of organic foods-value segments and liking of bread. Food quality and preference, 18(3), 471-481.

Kittisuban, P., Ritthiruangdej, P., \& Suphantharika, M. (2014). Optimization of hydroxypropylmethylcellulose, yeast $\beta$-glucan, and whey protein levels based on physical properties of gluten-free rice bread using response surface methodology. LWT - Food Science and Technology, 57(2), 738-748. doi:10.1016/j.Iwt.2014.02.045

Lazaridou, A., Duta, D., Papageorgiou, M., Belc, N., \& Biliaderis, C. (2007). Effects of hydrocolloids on dough rheology and bread quality parameters in gluten-free formulations. Journal of Food Engineering, 79(3), 1033-1047.

Mancebo, C., Merino, C., Martínez, M., \& Gómez, M. (2015). Mixture design of rice flour, maize starch and wheat starch for optimization of gluten free bread quality. Journal of Food Science and Technology, 52(10), 6323-6333. doi:10.1007/s13197-015-1769-4

Mancebo, C. M., San Miguel, M. Á., Martínez, M. M., \& Gómez, M. (2015). Optimisation of rheological properties of gluten-free doughs with HPMC, psyllium and different levels of water. Journal of Cereal Science, 61, 8-15. doi:10.1016/j.jcs.2014.10.005

Marcoa, C., \& Rosell, C. M. (2008). Effect of different protein isolates and transglutaminase on rice flour properties. Journal of Food Engineering, 84(1), 132-139. doi:10.1016/j.jfoodeng.2007.05.003

Matos, M. E., \& Rosell, C. M. (2012). Relationship between instrumental parameters and sensory characteristics in gluten-free breads. European Food Research and Technology, 235(1), 107-117. doi:10.1007/s00217-012-1736-5 
Matos, M. E., \& Rosell, C. M. (2013). Quality Indicators of Rice-Based Gluten-Free Bread-Like Products: Relationships Between Dough Rheology and Quality Characteristics. Food and Bioprocess Technology, 6(9), 2331-2341. doi:10.1007/s11947-012-0903-9

Matos Segura, M. E., \& Rosell, C. M. (2011). Chemical Composition and Starch Digestibility of Different Gluten-free Breads. Plant Foods for Human Nutrition, 66(3), 224-230. doi:10.1007/s11130-011-0244-2

Murray, J. A. (2005). Celiac disease in patients with an affected member, type 1 diabetes, irondeficiency, or osteoporosis? Gastroenterology, 128(4), S52-S56. doi:10.1053/j.gastro.2005.02.029

Ngemakwe, P. N., Le Roes-Hill, M., \& Jideani, V. (2015). Advances in gluten-free bread technology. Food Science and Technology International, 21(4), 256-276. doi:10.1177/1082013214531425

Nicolae, A., Radu, G.-L., \& Belc, N. (2016). Effect of sodium carboxymethyl cellulose on gluten-free dough rheology. Journal of Food Engineering, 168, 16-19. doi:10.1016/j.jfoodeng.2015.07.006

Nunes, M. H. B., Ryan, L. A. M., \& Arendt, E. K. (2009). Effect of low lactose dairy powder addition on the properties of gluten-free batters and bread quality. European Food Research and Technology, 229(1), 31-41. doi:10.1007/s00217-009-1023-2

Sabanis, D., \& Tzia, C. (2011). Effect of hydrocolloids on selected properties of gluten-free dough and bread. Food Science and Technology International, 17(4), 279-291. doi:10.1177/1082013210382350

Sciarini, L. S., Ribotta, P. D., León, A. E., \& Pérez, G. T. (2010). Influence of Gluten-free Flours and their mixtures on batter properties and bread quality. Food and Bioprocess Technology, 3(4), 577-585. doi:10.1007/s11947-008-0098-2

Singh, J., Dartois, A., \& Kaur, L. (2010). Starch digestibility in food matrix: a review. Trends in Food Science \& Technology, 21(4), 168-180. doi:10.1016/j.tifs.2009.12.001

Singh, N., Kaur, L., Sandhu, K. S., Kaur, J., \& Nishinari, K. (2006). Relationships between physicochemical, morphological, thermal, rheological properties of rice starches. Food Hydrocolloids, 20(4), 532-542. doi:10.1016/j.foodhyd.2005.05.003

Smyth, D. J., Plagnol, V., Walker, N. M., Cooper, J. D., Downes, K., Yang, J. H., . . Wijmenga, C. (2008). Shared and distinct genetic variants in type 1 diabetes and celiac disease. New England Journal of Medicine, 359(26), 2767-2777.

Souza, D. d., Sbardelotto, A. F., Ziegler, D. R., Marczak, L. D. F., \& Tessaro, I. C. (2016). Characterization of rice starch and protein obtained by a fast alkaline extraction method. Food Chemistry, 191, 36-44. doi:http://dx.doi.org/10.1016/j.foodchem.2015.03.032

Sun, J., Hou, C., \& Zhang, S. (2008). Effect of protein on the rheological properties of rice flour. Journal of Food Processing and Preservation, 32(6), 987-1001.

Tara, K., Bains, G., \& Finney, P. (1972). Damaged starch and protein contents in relation to water absorption of flours of Indian wheats. Starch-Stärke, 24(10), 342-345.

Tester, R., Qi, X., \& Karkalas, J. (2006). Hydrolysis of native starches with amylases. Animal Feed Science and Technology, 130(1), 39-54.

Varavinit, S., Shobsngob, S., Varanyanond, W., Chinachoti, P., \& Naivikul, O. (2003). Effect of amylose content on gelatinization, retrogradation and pasting properties of flours from different cultivars of Thai rice. Starch-Stärke, 55(9), 410-415.

Wani, A. A., Singh, P., Shah, M. A., Schweiggert-Weisz, U., Gul, K., \& Wani, I. A. (2012). Rice starch diversity: Effects on structural, morphological, thermal, and physicochemical propertiesA review. Comprehensive Reviews in Food Science and Food Safety, 11(5), 417-436. 
Wani, I. A., Sogi, D. S., Wani, A. A., \& Gill, B. S. (2013). Physico-chemical and functional properties of flours from Indian kidney bean (Phaseolus vulgaris L.) cultivars. LWT-Food Science and Technology, 53(1), 278-284.

Yamin, F., Lee, M., Pollak, L., \& White, P. (1999). Thermal properties of starch in corn variants isolated after chemical mutagenesis of inbred line B73 1. Cereal Chemistry, 76(2), 175181.
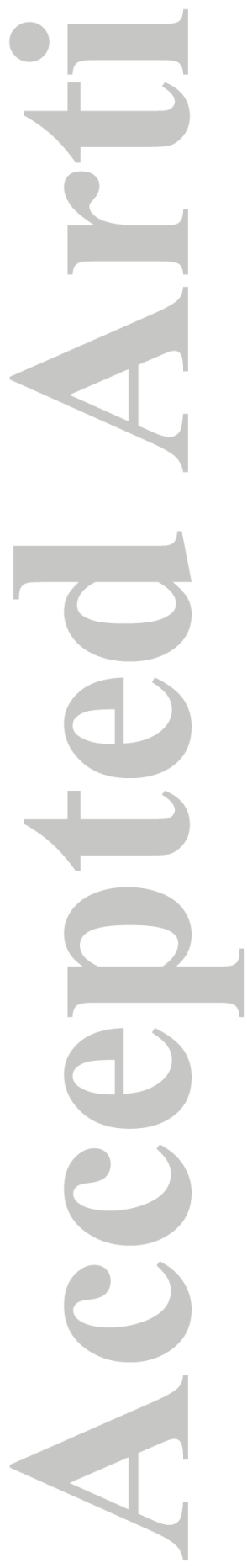


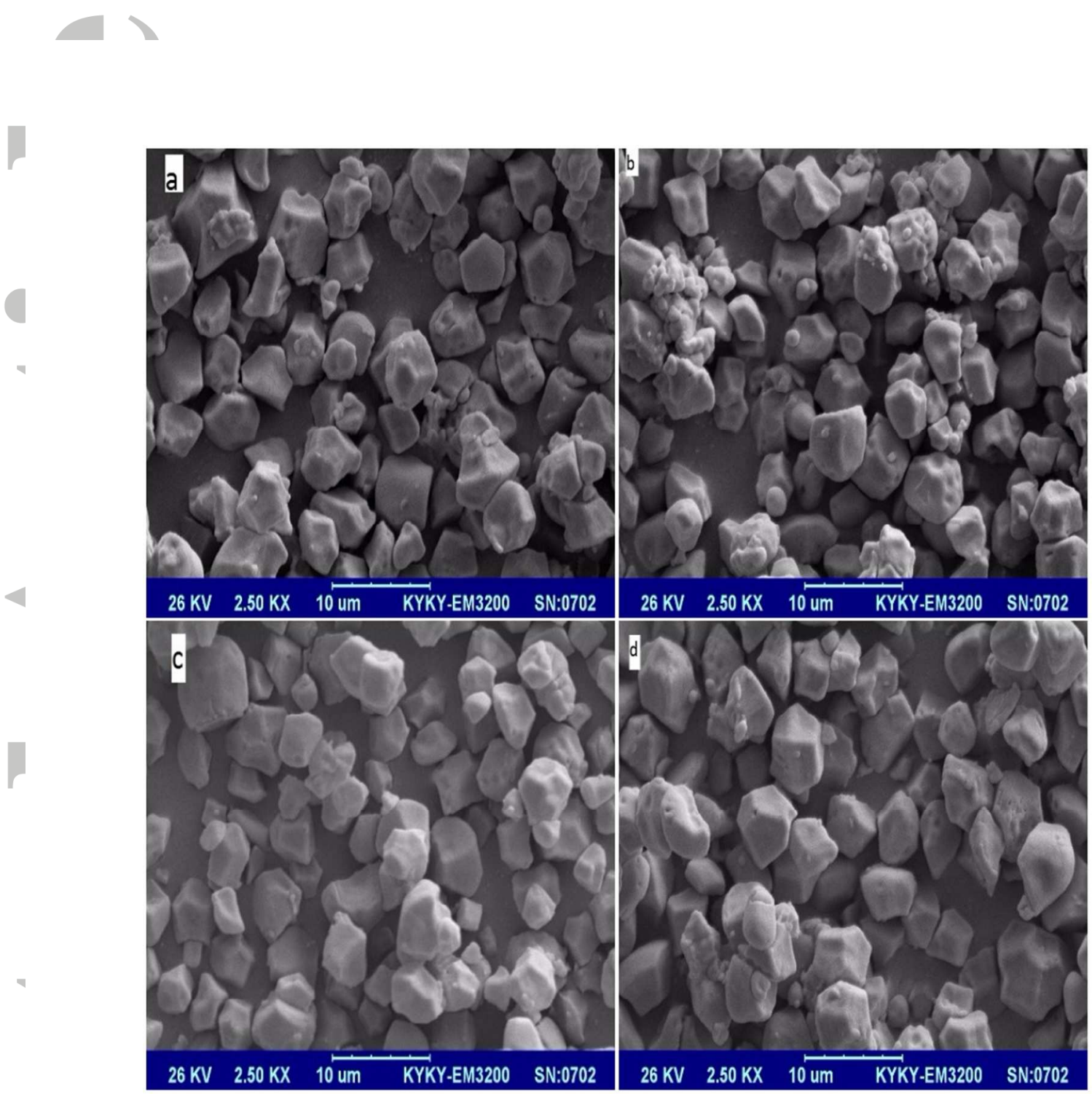

Fig. 1 Scanning electron micrographs of starches from different rice cultivars: a) Tarom; b) Khouzestan; c) Lenjan; d) Hashemi

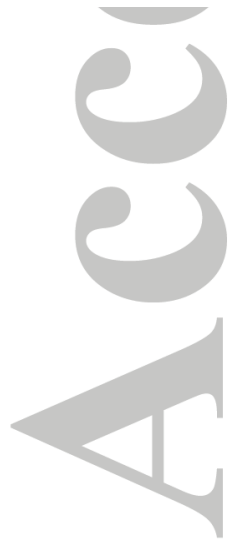




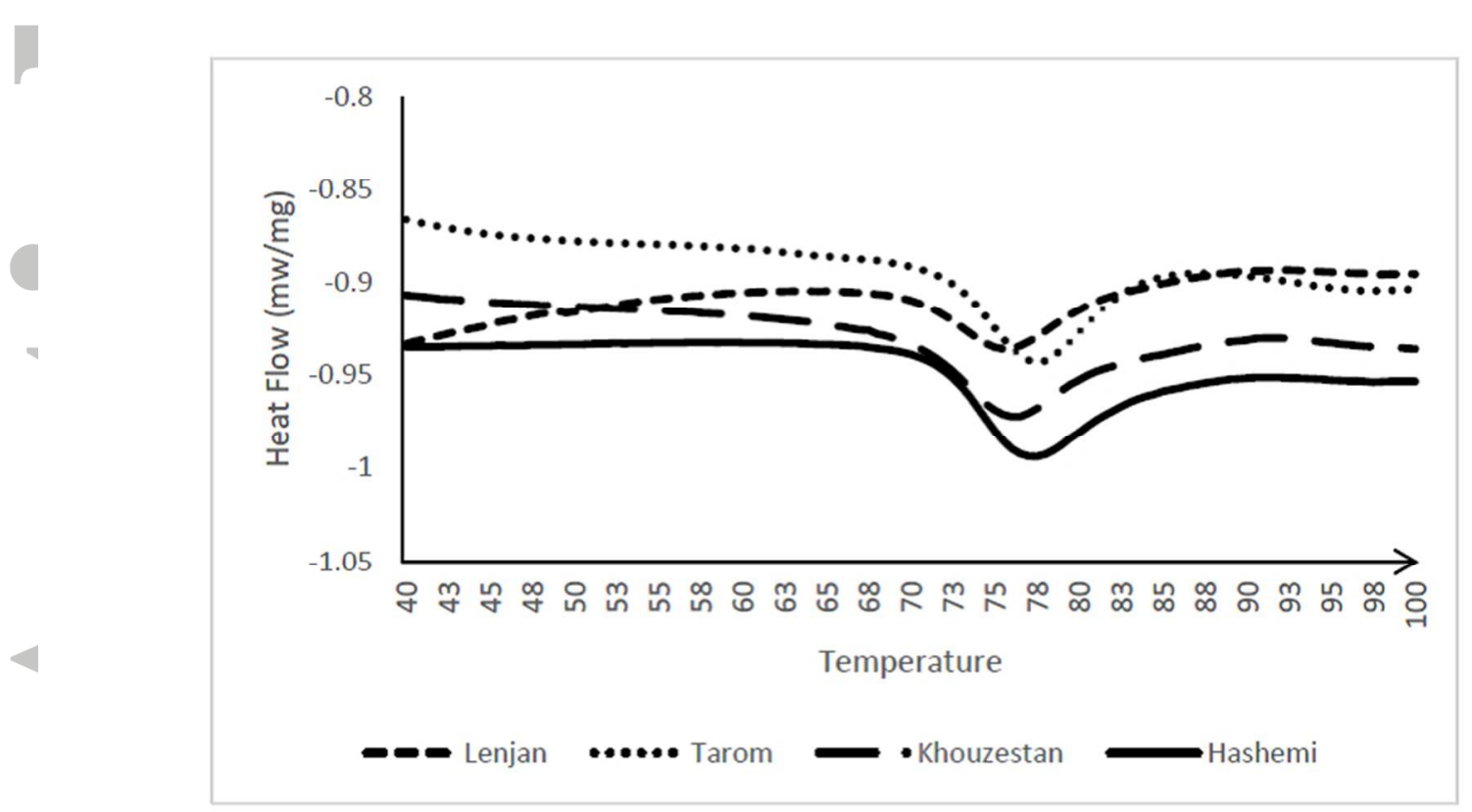

Fig. 2 Thermograms of different rice flours

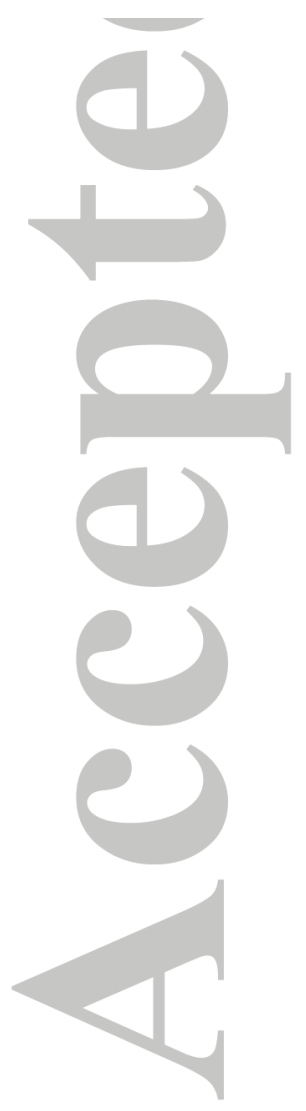




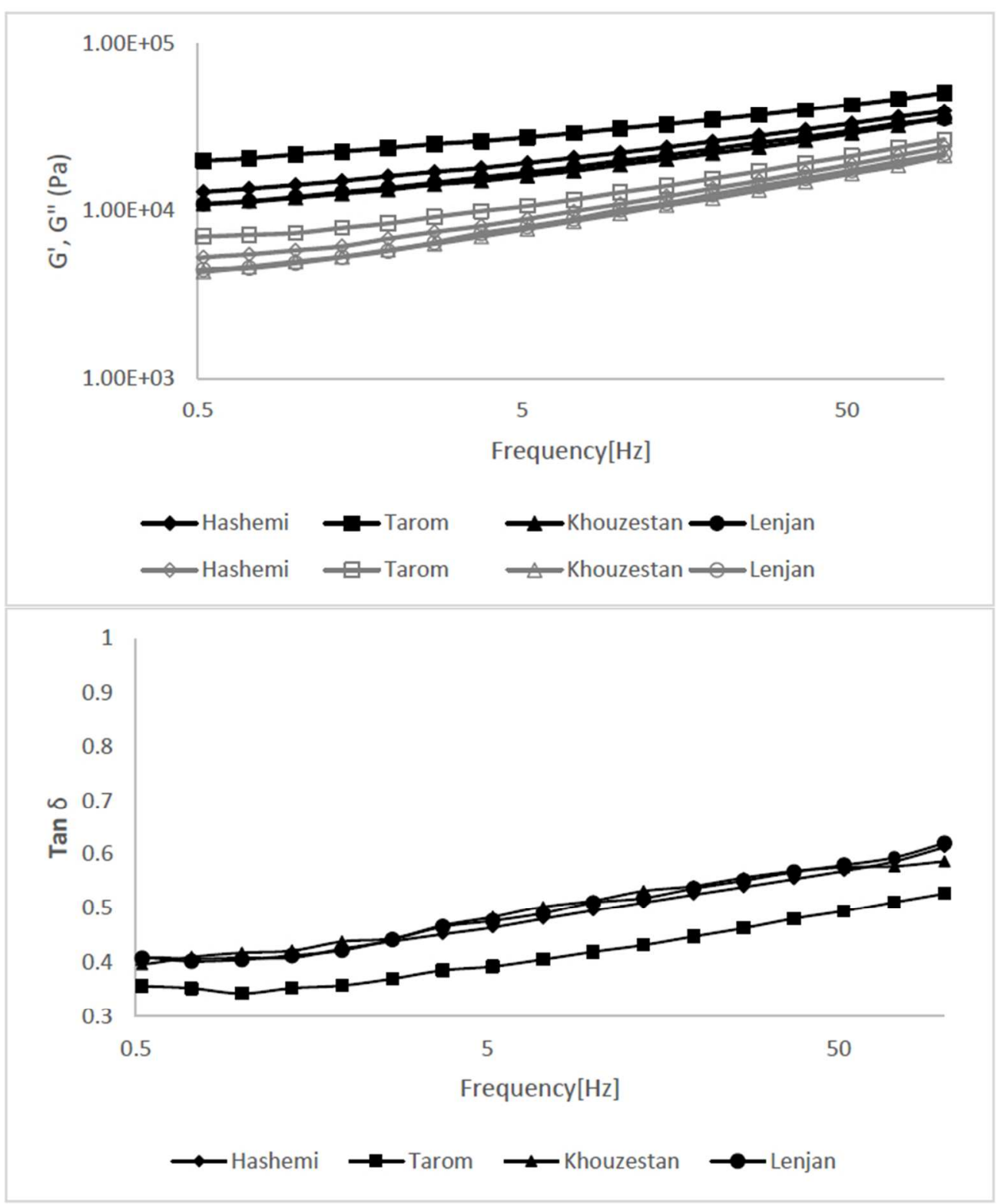

Fig. 3 Evaluation of dynamic moduli (G', G') and tan $\delta$ of dough samples at 25 oC. Filled symbols: G', open symbols G"

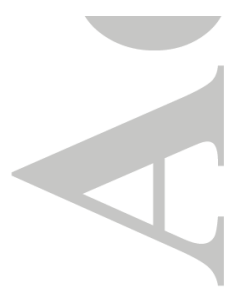




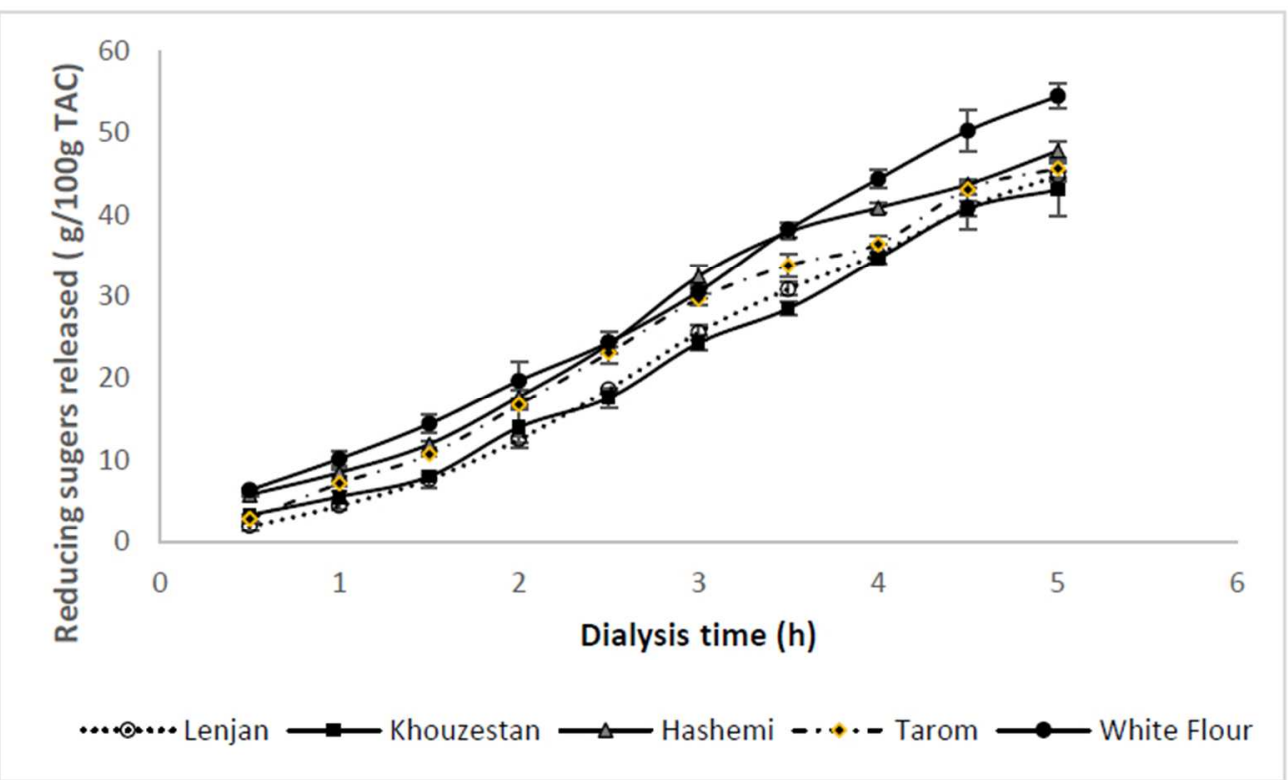

Fig. 4 Reducing sugars released from $4 \mathrm{~g}$ of samples during hydrolysis

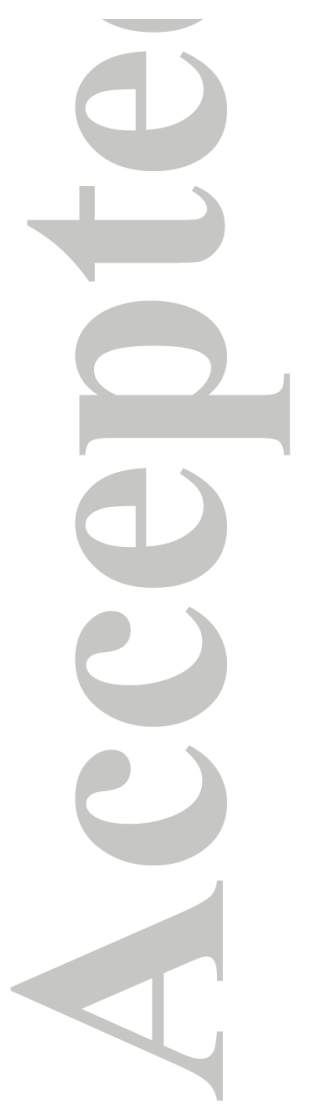

This article is protected by copyright. All rights reserved. 
Table 1. Proximate composition and hydration properties of rice-flour varieties

\begin{tabular}{|l|l|l|l|l|}
\hline Characteristics & Hashemi & Tarom & Khouzestan & Lenjan \\
\hline AAC $(\mathrm{g} / 100 \mathrm{~g})$ & $21.38 \pm 0.31 \mathrm{~d}$ & $23.57 \pm 0.55 \mathrm{c}$ & $24.80 \pm 0.27 \mathrm{~b}$ & $25.72 \pm 0.4 \mathrm{a}$ \\
\hline Damaged starch $(\mathrm{g} / 100 \mathrm{~g})$ & $14.83 \pm 0.79 \mathrm{~b}$ & $12.03 \pm 0.27 \mathrm{~d}$ & $13.46 \pm 0.34 \mathrm{c}$ & $17.45 \pm 0.26 \mathrm{a}$ \\
\hline Ash $(\mathrm{g} / 100 \mathrm{~g})$ & $0.79 \pm 0.01 \mathrm{c}$ & $0.61 \pm 0.13 \mathrm{~d}$ & $2.16 \pm 0.05 \mathrm{a}$ & $1.45 \pm 0.08 \mathrm{~b}$ \\
\hline Fat $(\mathrm{g} / 100 \mathrm{~g})$ & $1.42 \pm 0.32 \mathrm{~b}$ & $0.74 \pm 0.04 \mathrm{c}$ & $2.36 \pm 0.36 \mathrm{a}$ & $2.96 \pm 0.43 \mathrm{a}$ \\
\hline Protein $(\mathrm{g} / 100 \mathrm{~g})$ & $8.91 \pm 0.05 \mathrm{~d}$ & $9.49 \pm 0.07 \mathrm{c}$ & $11.7 \pm 0.05 \mathrm{a}$ & $10.21 \pm 0.2 \mathrm{~b}$ \\
\hline Moisture content $(\mathrm{g} / 100 \mathrm{~g})$ & $8.39 \pm 0.12 \mathrm{c}$ & $8.93 \pm 0.24 \mathrm{~b}$ & $9.71 \pm 0.26 \mathrm{a}$ & $8.72 \pm 0.13 \mathrm{bc}$ \\
\hline WHC $(\mathrm{g} / \mathrm{g})$ & $1.30 \pm 0.06 \mathrm{~b}$ & $1.52 \pm 0.05 \mathrm{a}$ & $1.49 \pm 0.01 \mathrm{a}$ & $1.23 \pm 0.04 \mathrm{~b}$ \\
\hline WBC $(\mathrm{g} / \mathrm{g})$ & $1.00 \pm 0.06 \mathrm{~b}$ & $1.21 \pm 0.01 \mathrm{a}$ & $0.98 \pm 0.01 \mathrm{~b}$ & $0.98 \pm 0.03 \mathrm{~b}$ \\
\hline
\end{tabular}

AAC: Apparent Amylose Content

Values with different letters within a row are significantly different $(\mathrm{P}<0.05),(\mathrm{n}=3)$

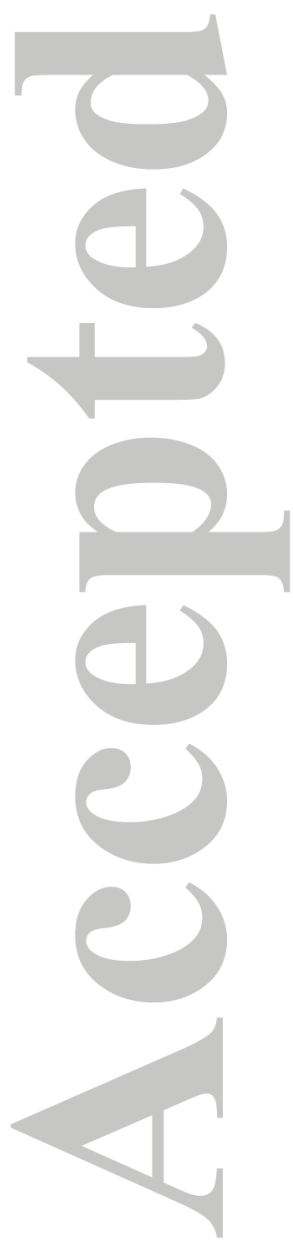


Table 2. Gelatinization parameters of flours from different rice varieties

\begin{tabular}{|l|l|l|l|l|l|l|}
\hline Variety & $\mathrm{T}_{\mathrm{o}}\left({ }^{\circ} \mathrm{C}\right)$ & $\mathrm{T}_{\mathrm{p}}\left({ }^{\circ} \mathrm{C}\right)$ & $\mathrm{T}_{\mathrm{c}}\left({ }^{\circ} \mathrm{C}\right)$ & $\mathbf{\Delta H}(\mathrm{J} / \mathrm{g})$ & $\mathrm{I}_{\mathrm{g}}\left({ }^{\circ} \mathrm{C}\right)$ & $\mathrm{PHI}$ \\
\hline Hashemi & $71.9 \pm 0.4 \mathrm{ab}$ & $77.5 \pm 0.7 \mathrm{a}$ & $83.4 \pm 0.9 \mathrm{a}$ & $2.54 \pm 0.6 \mathrm{a}$ & $11.5 \pm 0.5 \mathrm{a}$ & $0.44 \pm 0.08 \mathrm{a}$ \\
\hline Tarom & $72.5 \pm 0.6 \mathrm{a}$ & $77.6 \pm 0.6 \mathrm{a}$ & $83.2 \pm 1 \mathrm{a}$ & $2.21 \pm 0.68 \mathrm{a}$ & $10.7 \pm 0.4 \mathrm{ab}$ & $0.43 \pm 0.13 \mathrm{a}$ \\
\hline Khouzestan & $71.0 \pm 0.5 \mathrm{bc}$ & $76.3 \pm 1.2 \mathrm{a}$ & $81.0 \pm 0.7 \mathrm{~b}$ & $2.45 \pm 0.31 \mathrm{a}$ & $10.0 \pm 0.2 \mathrm{c}$ & $0.46 \pm 0.01 \mathrm{a}$ \\
\hline Lenjan & $70.7 \pm 0.8 \mathrm{c}$ & $76.2 \pm 0.6 \mathrm{a}$ & $81.7 \pm 0.9 \mathrm{ab}$ & $1.79 \pm 0.2 \mathrm{a}$ & $11.0 \pm 0.1 \mathrm{ab}$ & $0.32 \pm 0.05 \mathrm{a}$ \\
\hline
\end{tabular}

Values with different letters in the same column are significantly different $(\mathrm{P}<0.05),(\mathrm{n}=3)$

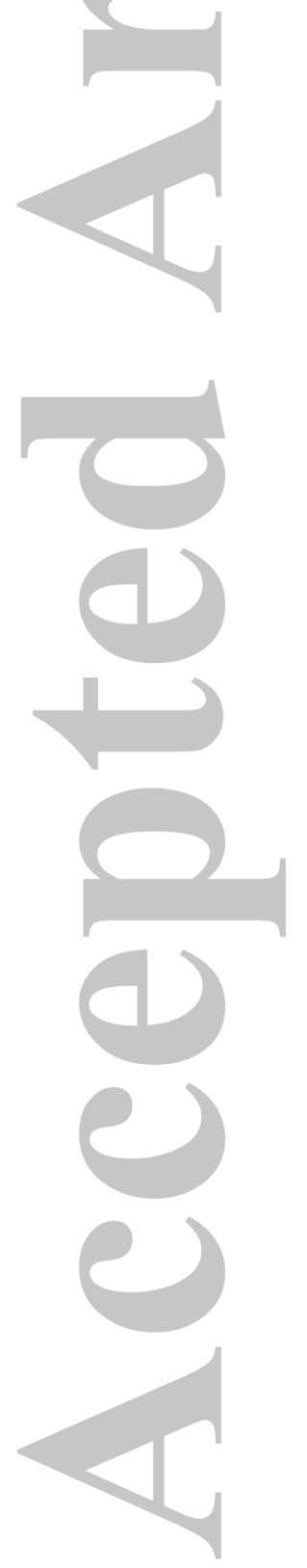


Table 3. Crumb-color parameters

\begin{tabular}{|l|l|l|l|}
\hline Variety & $\mathbf{L}^{*}$ & $\mathbf{a}^{*}$ & $\mathbf{b}^{*}$ \\
\hline Hashemi & 72.53 & -0.97 & 14.56 \\
\hline Tarom & 76.32 & -0.74 & 13.38 \\
\hline Khouzestan & 70.26 & -0.96 & 14.16 \\
\hline Lenjan & 70.46 & -0.65 & 16.37 \\
\hline & & & \\
\end{tabular}

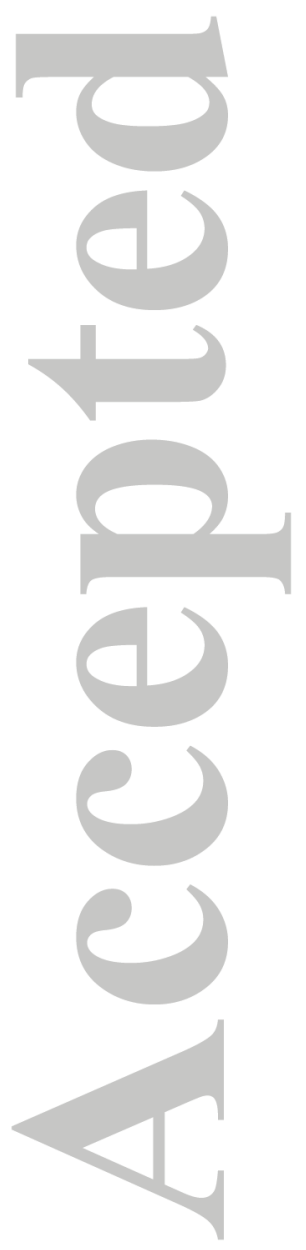

This article is protected by copyright. All rights reserved. 
Table 4. Quality parameters of gluten-free breads

\begin{tabular}{|l|l|l|l|l|}
\hline Rice varieties & Hashemi & Tarom & Khouzestan & Lenjan \\
\hline $\begin{array}{l}\text { Specific } \\
\text { volume }, \mathrm{cm}^{3} / \mathrm{g}\end{array}$ & $1.95 \pm .06 \mathrm{a}$ & $1.80 \pm 0.03 \mathrm{~b}$ & $2.02 \pm 0.06 \mathrm{a}$ & $1.92 \pm 0.04 \mathrm{a}$ \\
\hline Hardness (N) & $2.93 \pm 0.2 \mathrm{~b}$ & $4.14 \pm 0.08 \mathrm{a}$ & $2.20 \pm 0.04 \mathrm{~d}$ & $2.57 \pm 0.14 \mathrm{c}$ \\
\hline Springiness & $0.98 \pm 0.04 \mathrm{a}$ & $0.97 \pm 0.02 \mathrm{a}$ & $0.99 \pm 0.02 \mathrm{a}$ & $0.97 \pm 0.00 \mathrm{a}$ \\
\hline Cohesiveness & $0.70 \pm 0.01 \mathrm{~b}$ & $0.75 \pm 0.01 \mathrm{a}$ & $0.71 \pm 0.01 \mathrm{~b}$ & $0.68 \pm 0.02 \mathrm{~b}$ \\
\hline Chewiness (N) & $2.05 \pm 0.10 \mathrm{~b}$ & $3.11 \pm 0.09 \mathrm{a}$ & $1.57 \pm 0.06 \mathrm{c}$ & $1.73 \pm 0.15 \mathrm{c}$ \\
\hline Resilience & $0.44 \pm 0.01 \mathrm{~b}$ & $0.49 \pm 0.01 \mathrm{a}$ & $0.44 \pm 0.00 \mathrm{~b}$ & $0.42 \pm 0.01 \mathrm{c}$ \\
\hline
\end{tabular}

Values with different letters within a row are significantly different $(\mathrm{P}<0.05),(\mathrm{n}=3)$

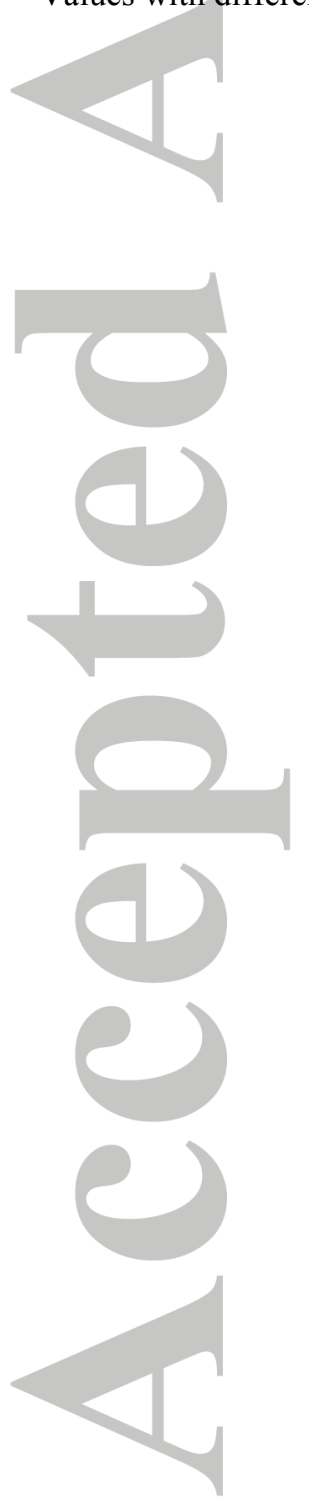


Table 5. Hydrolysis index (HI) and predicted glycemic index $\left(\mathrm{GI}_{\text {predicted }}\right)$ of rice-bread samples

\begin{tabular}{lll}
\hline Bread rice samples & $\mathrm{HI}(\%)$ & $\mathrm{GI}_{\text {predicted }}$ \\
\hline White-flour bread & - & $100^{\mathrm{a}}$ \\
Tarom rice bread & $84.6 \pm 1.6^{\mathrm{b}}$ & $81.14 \pm 1.3^{\mathrm{c}}$ \\
Hashemi rice bread & $94.57 \pm 1.7^{\mathrm{a}}$ & $89.7 \pm 1.4^{\mathrm{b}}$ \\
Khouzestan rice bread & $68 \pm 2.8^{\mathrm{c}}$ & $66.8 \pm 2.4^{\mathrm{d}}$ \\
Lenjan rice bread & $65.1 \pm 2.3^{\mathrm{c}}$ & $64.2 \pm 2.0^{\mathrm{d}}$ \\
\hline
\end{tabular}

Values with different letters in the same column are significantly different $(\mathrm{P}<0.05),(\mathrm{n}=3)$
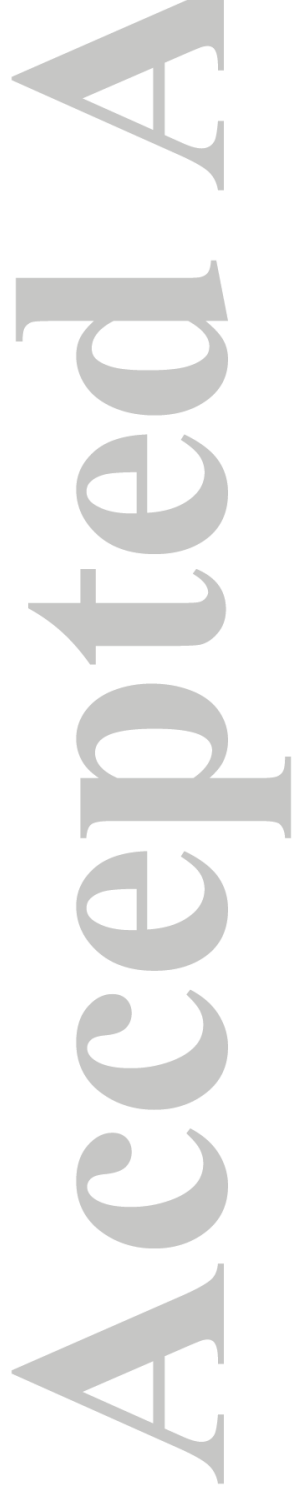
Table 6. Sensory analysis of gluten-free breads

\begin{tabular}{|c|c|c|c|c|}
\hline Sensorial Parameters & Hashemi & Tarom & Khouzestan & Lenjan \\
\hline Appearance & $4.36 \pm 0.80 \mathrm{a}$ & $2.81 \pm 1.40 \mathrm{~b}$ & $4 \pm 1.34 \mathrm{ab}$ & $4.36 \pm 0.80 \mathrm{a}$ \\
\hline Color & $4.09 \pm 0.70 \mathrm{a}$ & $3 \pm 1.18 \mathrm{~b}$ & $4.36 \pm 1.02 \mathrm{a}$ & $4.45 \pm 0.65 \mathrm{a}$ \\
\hline Odor & $3.36 \pm 1.36 \mathrm{a}$ & $3.54 \pm 1.21 \mathrm{a}$ & $3.72 \pm 1.10 \mathrm{a}$ & $3.27 \pm 1.48 \mathrm{a}$ \\
\hline Taste & $3.18 \pm 1.07 \mathrm{a}$ & $3.54 \pm 0.93 \mathrm{a}$ & $3.90 \pm 0.70 \mathrm{a}$ & $3.27 \pm 1.19 \mathrm{a}$ \\
\hline Texture & $4 \pm 1.26 \mathrm{a}$ & $3.9 \pm 1.04 \mathrm{a}$ & $4.45 \pm 0.52 \mathrm{a}$ & $3.81 \pm 1.32 \mathrm{a}$ \\
\hline Overall & $3.72 \pm 0.90 \mathrm{a}$ & $3.54 \pm 0.82 \mathrm{a}$ & $4.27 \pm 0.64 \mathrm{a}$ & $3.81 \pm 1.07 \mathrm{a}$ \\
\hline
\end{tabular}

Evaluation was made on a five-point hedonic scale from 1 (dislike extremely) to 5 (like extremely).Values with different letters within a row are significantly different $(\mathrm{P}<0.05)$

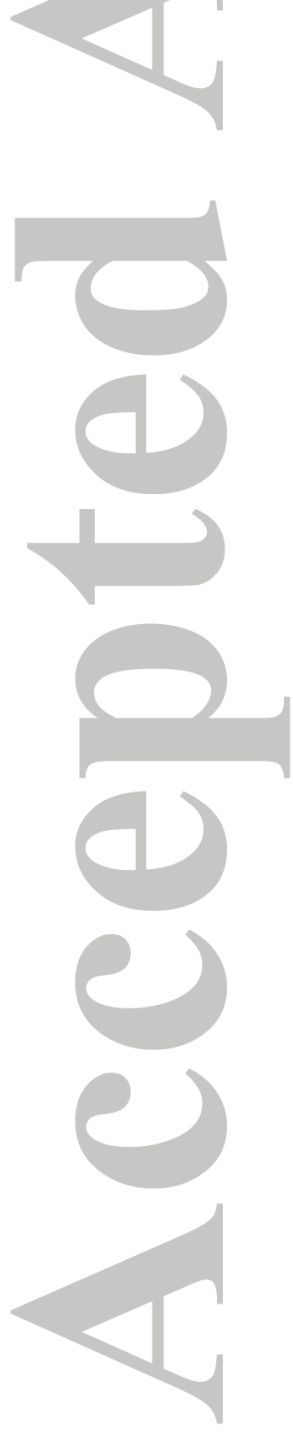

